LETTERS

\section{Bad behaviour does not equal research fraud}

I was not impressed by Dr Geggie's article offering a survey of the attitudes of newly appointed consultants towards research fraud (Journal of Medical Ethics 2001;27:344-6). Indeed, by mixing up categories of misconduct from what is at most "bad behaviour" to the very serious, he is not entirely beyond reproach himself. I remind readers that $\mathrm{Dr}$ Geggie suggested that $55.7 \%$ of the respondents had observed (from the title) "research fraud".

If the term "research fraud" is to have any meaning, it must be reserved for conduct that consciously and deliberately attempts to impose a fraud on others. The US National Academy of Sciences' report, On Being a Scientist: Responsible Conduct in Research distinguishes clearly between "misallocation of credit, honest errors, and errors caused through negligence" and "deception, making up data or results, changing or misreporting data or results, and plagiarism". The former are "ethical transgressions ... that generally remain internal to the scientific community ... dealt with locally through peer review, administrative action, and the system of appointments and evaluations". The latter "strike at the heart of the values on which science is based". The White House's Office of Science and Technology Policy reached similar conclusions, restricting research misconduct to "fabrication, falsification and plagarism". I agree with these assessments.

In Dr Geggie's paper, deception would include deliberate falsification of data (category 3 of Dr Geggie's table 1), cheating (4A) and deliberately plagiarising without attribution (4D). We then move into fairyland, because Dr Geggie next asks "have you ever been an author on a paper for which any of the authors have not made a sufficient contribution to warrant credit for the work" or "has your name ever been omitted from a paper for which you had made a substantial contribution", and, surprise, surprise, over half answered yes. These are examples of, at worst, ethical transgressions (but more often examples of delusions of grandeur on the part of the offended) but are not research fraud.

Those of us who run large research groups know from experience that authorship of any paper poses problems. I have never met anyone, from the cleaner to the director, who undervalued his/her own contribution to the work! The issue arises with such consistency that many labs (including my own) have long documents on how to resolve the problem of who goes on, and who stays off, the authors' list. But research fraud? Give me a break!

Of those who responded, approximately $10 \%$ had personal knowledge of research fraud, and $5 \%$ at most (it is not possible to tel if there is overlap between those answering different questions) admitted to acts that could be regarded as research fraud. This corresponds to my own experience. I have spent more than 40 years in human molecular genetics, a very competitive field, of which 25 years has been spent running very large groups. I know the work of over 1000 scientists well. I have personal knowledge of one case of serious research fraud and perhaps three or four cases where the reporting of data was so careless as to verge on misconduct (though without intent to commit fraud). I also know of one case of plagiarism. To blur the boundaries between "research fraud", "research misconduct", "possible future misconduct", and complaining about not getting your name on a paper does no one any good, and certainly does not help any rational discussion about research ethics.

Bob Williamson

The Murdoch Childrens Research Institute, 10th Floor, Royal Children's Hospital, Flemington Road, Parkville Vic 3052, Australia williamb@cryptic.rch.unimelb.edu.au

\section{Author's reply}

Professor Williamson makes a valid point about the term "research fraud" and I agree that the term covers a number of different categories of unethical behaviour. I also pointed out that "Research fraud can take many forms" in the discussion section of my paper (Journal of Medical Ethics 2001;27:344-6) For the purposes of my article I stated that consultants who had answered "Yes" to questions 1,2 , or 3 of table 1 had reported "observed misconduct" and I stand by this conclusion. The dictionary on my bookshelf (Concise Oxford Dictionary (6th ed)) defines "misconduct" as "improper conduct, esp. adultery; bad management" and I think that what the consultants were reporting in the questionnaire fits this definition. The same dictionary includes in its definition of "fraud" the phrases "use of false representations to gain unjust advantage" and "person or thing not fulfilling expectation or description". The behaviour described in questions 1,2 , and 3-that is inappropriate authorship, omission of names of contributors who made a substantial contribution, and the intentional alteration of data for publication, fits this definition. In the article I tried to use the term "fraud" as a more general term than "misconduct" and I apologise if this caused confusion. I think, however, that the majority of readers (and certainly the majority of my colleagues) would have had something approaching the above definitions in mind when they read the article (although several colleagues have told me to get a more up-to-date dictionary!) Whilst I acknowledge that Professor Williamson makes a valid point, $I$ do think there is a danger of any rational discussion becoming bogged down in semantics and I think it is clear from my article what the initial data was and how I have derived my variables.

Professor Williamson dismisses the medical consultants (not cleaners!) who answered yes to questions 1 and 2 as having "more often delusions of grandeur" on their part. That is a point of view-but I suspect the majority of respondents to my questionnaire do not share it. Indeed I think his attitude risks sweeping a very real problem under the carpet and, whilst I am aware of attempts to standardise authorship, I think this is a problem which requires further investigation.

I find the overall tone of this letter and phrases such as "into fairyland" and "give me a break" inflammatory and this, unfortunately, distracts from some valid points.

Professor Williamson's main criticism appears to be that he has learnt nothing new from my paper. The original idea for this study came after a lively discussion in a bar about the prevalence of research fraud (a subject of which I knew very little). After this discussion I did a literature search and could find only a few references to research fraud and misconduct. I decided to perform the study in an attempt to answer the questions I had. I wish that Professor Williamson had been present at the original discussion-he could have saved me a lot of trouble! On a more serious note, I am sure that the professor is aware that in the "hierarchy of evidence" questionnaire surveys rank higher than anecdotal evidence and personal experience (although only just!). The value of my article is that it adds evidence to a subject in which there is a marked paucity of hard facts.

I am sorry that Professor Williamson was unimpressed with my paper. Unfortunately, the very nature of the subject of research fraud/misconduct mitigates against good quality research. I am sure that readers would welcome any double-blinded randomised control trials (RCTs) on the subject and, if the professor wishes to carry out some research in this area I am sure that the scientific community would welcome it.

\section{Accident and Emergency Department, Arrowe Park Hospital, Arrowe Park Road, Upton, Wirral, Merseyside CH49 5PE, UK DAVID@GEGGIE.freeserve.co.uk \\ Ethical implications of consent and confidentiality}

D Geggie

Recently a prospective, observational clinical study was carried out in the department of ophthalmology, at a district general hospital. The main purpose of the study was to evaluate the medicolegal and ethical implication of consent and confidentiality in ophthalmic practice, in accordance with the guidelines provided by medical law.

One hundred patients, who had been referred by optometrists to ophthalmologists, were included in the study. The general ophthalmic services (GOS) 18 form, a referra form used by optometrists for referring patients to ophthalmologists, which allows optometrists to share a patient's medica information with ophthalmologists, was used as a study tool to evaluate the percentage of patients giving signatory consent

Data was also collected regarding patients awareness about the medicolegal implications of consent and their views about their medical information being shared among different health care professionals in ophthalmic practice.

The results of our study show that only 15\% of GOS 18 forms contained written consent by the patients for information to be shared by their optometrist. The remaining $85 \%$ were referred without obtaining an express written consent.

These results were further supported by the information generated from a questionnaire filled in by patients attending the eye clinics. The questionnaire includes the following three simple questions: responses are alongside. 
Are you aware about the fact that you should be consented by your optometrist on the referral form? Yes/No (46\% / 54\%)

Did your optometrist explain to you about the consent statement mentioned on the GOS 18 form? Yes/No (40\% / 60\%)

Would you like the ophthalmologist to make available your medical information to your optometrist/ophthalmic medical practitioner? Yes/No (85\% / 15\%)

\section{Conclusion}

Only a few GOS 18 forms contained patients written consent for information to be sent back to the referring optometrist.

Fifteen per cent of the patients surveyed, said they did not wish information to be shared with their optometrists. Therefore we should be careful about sending back information to optometrists where signatory consent has not been given.

Optometrists need to be aware of this potential issue. In the light of the increasingly close relationship between optometrists and ophthalmologists (especially where they share care for glaucoma and postoperative cataract patients) it is important for the optometrist that consent is given if feedback is required

\section{Discussion}

A good doctor-patient relationship can be defined by the three Cs: (i) Confidentiality, (ii) Consent, and (iii) Competence. If any of these three components are missing the doctorpatient relationship could be damaged and the flow of communication in both directions inhibited.

A promise on the part of the doctor to maintain patient confidentiality is central if patients are to be allowed to speak freely. If information is shared without the patient's consent then the faith of the patient in the doctor may be forfeited.

Consent is an integral part of the GOS 18 referral form but our study shows that it is taken for granted and is not handled in accordance with guidelines set out in medical law.

Y Khan

SHO Ophthalmology, Ashford Hospital, London Road, Middlesex, TW15 3AA, UK yasir1399@hotmail.com

R J Stirling

Darlington Memorial Hospital, Hollyhurst Road, Darlington, DL3 6HX, UK

\section{BOOK REVIEWS}

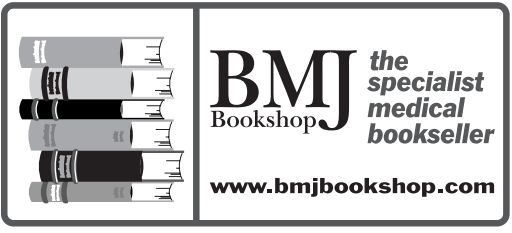

\section{Tuskegee's Truths: Rethinking the Tuskegee Syphilis Study}

Edited by S M Reverby. University of North Carolina Press, 2000, £52.50 (hc), £19.95 (sc), pp 630. ISBN 0-8078-4852-2

No one interested in the ethics of biomedical research will have failed to hear about the
Tuskegee syphilis study, or, to give it its full title, the US Public Health Service's Tuskegee Study of Untreated Syphilis in the Negro Male. This study, conducted from 1932 to 1972, on black (African American) males in Tuskegee, Alabama, has, with complete justification, become the paradigm of moral depravity in the field of biomedical research. Virtually every rule of good, ethical research was broken during this "research" over a period of 40 years, down to denying participants even the knowledge, let alone the option, of a remedy when it became available.

In recent years, the Tuskegee syphilis study has received renewed public attention, for two reasons. First, in 1996, 24 years after the cessation of the study, President Clinton provided a formal federal apology, saying to the survivors that " $[\mathrm{w}] \mathrm{e}$ can look at you in the eye and finally say on behalf of the American people, what the United States governmen did was shameful, and I am sorry". With this apology, Clinton not only accepted moral responsibility—something not easily done by governments in the affairs of state, domestic or foreign — but also contributed to addressing African Americans' distrust of health care and biomedical research, a distrust fuelled by the legacy of Tuskegee.

Second, echoes of Tuskegee have been heard in the ongoing debate about the ethics of biomedical research financed or conducted in the developing world by government agencies and companies from the developed world, particularly in regard to HIV/AIDS. Such research raises ethical questions, relating to key issues such as exploitation and justice, informed consent, and duties of beneficence. David J Rothman puts the underlying concern as follows: "Until the 1990s American medical researchers performed most of their experiments on other Americans-frequently choosing subjects who were poor and vulnerable. Now, however, they are increasingly likely to conduct their investigations in third world countries on subjects who are even poorer and more vulnerable". ${ }^{1}$ HIV/AIDS and escaping the possibility of financial and regulatory burdens are cited as reasons for this shift. The ethics of Tuskegee has been internationalised.

For this reason, but also for several others, Susan M Reverby's edited volume, Tuskegee's Truths: Rethinking the Tuskegee Syphilis Study, is a welcome, and indeed magisterial, addition to the Tuskegee literature. In a volume of 630 pages, the editor has put together a resource containing virtually everything one would wish to know about the Tuskegee studyinformation, transcripts of historical documents, reflections, moral lessons. In a single volume one gets a panorama, as well as detailed mapping, of this sorry saga in US biomedical ethics.

The book begins with an Overview (part I) and Contemporary background (part II). This is followed by an extensive section, Documenting the issues (part III), which includes material such as the testimony by four survivors from the United States Senate hearings on human experimentation, in 1973. Part IV focuses on The Question of treatment, while part $\mathrm{V}$ is an Historical reconsideration. The much debated role played by nurse Rivers is rethought in part VI. The Legacy of Tuskegee is considered in part VII, while Key actors rethink the study in part VIII. Part IX, Imagining the Tuskegee syphilis study, moves into the realm of fiction and poetry, with, among others, selections from the play, Miss Evers' Boys. The final part, part X, Apology and beyond, contains such significant recent documents as President Clinton's apology speech and Marcia Angell's 1997 editorial in the New England Journal of Medicine.

I strongly recommend this important volume for anyone interested in the ethics of biomedical research. By rethinking the past we may understand the dangers inherent in such research. From the perspective of the developing world, we need to be armed with the knowledge to help us prevent history from repeating itself, at least in this respect.

W A Landman

\section{Reference}

1 Rothman DJ. The shame of medical research. The New York Review of Books 2000;XLVII:60-4.

\section{Genes, Women, Equality}

$M$ B Mahowald. Oxford University Press, 2000, US\$39.95 (hb), pp 314. ISBN 0-19$512110-4$

Far too often it is still assumed that if feminist bioethics has any role to play, its contribution lies purely in reproductive ethics. Mary Mahowald's Genes, Women, Equality should dispel that delusion once and for all, along with a second illusion: that the new genetics is gender-neutral.

Mahowald is not a bioethical Luddite: she is not concerned to attack the new genetics, but to make good the failure of bioethicists and scientists to explore the differential impact of the new genetics on women. Specific implications for women of advances in genetics in different fields form the bulk of the book, with chapters on genetic counselling; genetics research; allocation of genetic services; culture and sex selection; misattributed paternity and cystic fibrosis; sickle cell disease and carrier testing; breast cancer susceptibility testing; preimplantation genetic diagnosis and abortion; genomic alternation; genetically linked alcoholism, employment and insurance testing, and human cloning.

This last chapter is a prime example of the need for Mahowald's sort of analysis: how often is it recognised that even therapeutic cloning and stem cell research, such as was recently approved by the UK parliament, affect women differently from men? The obvious reason is that large numbers of enucleated eggs will be required, and that enucleated eggs come from women, taken in a painful and difficult procedure. But as Mahowald mildly notes, so far as the further step of human cloning goes: "Interestingly, while some bioethicists expressed concerns about the impact of human cloning on cloned individuals, none, to my knowledge, indicated that there were gender differences to worry about as well" (pages 281-2).

These practical chapters show Mahowald's clinical knowledge to good advantage (although a philosopher, she is professor in the college, the Department of Obstetrics and Gynecology, the Committee on Genetics and the MacLean Center for Clinical Medical Ethics at the University of Chicago.) Her analysis is particularly clear here, and in other "reprogenetics" chapters, especially in the distinction she draws between genetic, gestational, and lactational motherhood. She rightly draws our attention to a fourth form of motherhood which can also now occur: the provision of enucleated eggs, into which another set of genes is inserted. Which of these is "real" motherhood? 
There are also a series of "mid-level theory" chapters, such as that on Disabilities, feminism and caregiving, which is informed by the split in feminist thought between disability rights feminists such as Adrienne Asch, who distrust genetic screening and correlated abortion on the grounds that they discriminate against the disabled, and other feminists such as Christine Overall, ${ }^{1}$ or Mahowald herself, who distinguish between the legitimate abortion of fetuses with disabilities and advocacy for disabled people (and their carers, usually women). The analysis in both the "specific issues" and the "mid-level" chapters will be of enormous use to both practitioners and academics.

Mahowald also attempts to provide a normative foundation for the two less theoretical sorts of chapters, particularly in her chapter 4 , Gender justice in genetics. Here she employs what she terms a feminist standpoint approach or egalitarian feminist model, which directs our attention towards power imbalances. Where inequalities result from rectifiable social power imbalances rather than unalterable and value-neutral differences, the standpoint of the less powerful group should be privileged over that of the more powerful in this model. "Some differences entail inequalities; others are merely associated with them" (page 74). Inequalities which persist by mere association, such as the continued association of women with caregiving, are more easily rectifiable; biological differences, such as the fact that it is women who give birth, are harder to remedy, but we should try to minimise their impact. Certainly we should not allow necessary biological inequality to become an excuse for avoidable social inequality, but that is what some aspects of the new genetics risk doing.

The feminist standpoint model is frequently contrasted with a conservative libertarian model, as the theoretical overview which has so far dominated in the new genetics. While I agree with this part of Mahowald's analysis, I am less convinced that the liberal feminist model is always wrong, even though I do not count myself a liberal feminist. There is a certain risk of demonisation of the liberal feminist view, which Mahowald does no always avoid; it is not the same as libertarianism. On the whole, however, this is a vital book for anyone interested in the new genetics-yes, even for those who don't actually think they are also interested in feminism.

D Dickenson

\section{Reference \\ 1 Overall C. New reproductive technologies and practices: benefits or liabilities for children? In: Dickenson D, ed. Ethical issues in maternal-fetal medicine. Cambridge: Cambridge University Press, 2002. \\ On Dying Well: An Anglican Contribution to the Debate on Euthanasia}

Board for Social Responsibility of the Church of England, Church House Publishing, 2000, $£ 4.95,94$ pages, 0715165879

For any reader interested in euthanasia, On Dying Well gives an accessible yet detailed account of the Church of England's view on the subject. First published in 1975, this short report is the product of the Church's Board for Social Responsibility, which brought together theologians, philosophers, lawyers, and medical professionals to form a working party with the remit of examining euthanasia. The second edition of On Dying Well leaves most of the original working party report findings unaltered, but adds a new introduction by Professor Stuart Horner, chairman of the British Medical Association's ethics committee from 1989 to 1997. Other changes to the first edition are a redrafted chapter on the legal questions surrounding euthanasia in light of new cases pertinent to the debate and additional reflections on the report's medical content. Also included is an updated bibliography, listing publications produced after 1975 and, in appendix form, the 1993 Joint Submission to the House of Lords Select Committee on Medical Ethics made by the House of Bishops of the Church of England and the Roman Catholic Bishops' Conference of England and Wales.

On Dying Well is a report of broad-ranging scope which, not surprisingly, robustly rejects the legalisation of voluntary euthanasia. This rejection operates in two ways-marshalling both principled, theologically grounded rhetoric and more practical, medically orientated arguments and clinical case studies. Thus, in his introduction, while acknowledging that most churches "would now approve the language of human rights", Professor Horner rejects what he terms an "unbridled" notion of autonomy which ignores an "ultimate accountability to God". Then on a more practical level, he stresses the significan impact that developments in palliative care have had on care of the dying, arguing that in the vast majority of cases "there is almost no reason today for patients with an incurable condition to die in agony and distress". Lamenting that hospice care is not available to all terminally ill patients, Professor Horner nevertheless maintains that this is no reason to write euthanasia into the statute books. He dismisses arguments that focus on poor standards of terminal care as a justification for legalising euthanasia, adding that it seems "utterly illogical that if doctors are guilty of bad terminal care, society should then award them greater powers to remedy the problem".

This reference to the distribution of "power" within the doctor-patient relationship goes to the heart of the euthanasia debate, as conceptions of what constitutes "good death" are negotiated and renegotiated against a backdrop of ever-changing medical practice and wider societal values. There are those who do, of course, reject the view that the legalisation of euthanasia represents an allocation of "greater powers" to doctors, but instead view euthanasia as a crucial element in securing personal autonomy and self determination for the patient. When the Voluntary Euthanasia Society published its 1976 rejoinder to the first edition of On Dying Well it concluded that the church's report was "determined, and often distorted by ... an absolute prior rejection of euthanasia".

However, the focus of the church's report is largely on the potential implications of legalising euthanasia and interestingly, both the theological and the medical chapters of the book concede that there may be "exceptional cases" in which euthanasia is morally permissible. It is argued that such instances, judged by the report to be extremely rare, are best dealt with on a case by case basis rather than by altering the status of the law. The report concludes that the legalisation of euthanasia would have numerous damaging effects, including reducing the incentive to improve provision of care for the dying; placing patients under pressure to seek an end to their lives, and, ultimately, increasing the risk of non-voluntary euthanasia.

Some readers will be left unsatisfied by this endorsement of the "slippery slope" view of legalising euthanasia. Similarly, not every reader will be satisfied with the conclusion that euthanasia excludes the administration of drugs to relieve pain or distress, even if this does, on occasion, and as the report concedes, carry the risk of shortening life. On this front, the report is vulnerable to the charge that it retreats behind euphemisms-emphasising the proposed "intention" of a doctor solely to relieve pain, but avoiding difficult questions that accompany the acknowledgement that a patient's life may be shortened as a result. Nevertheless, the medical and theological pragmatism of the report stands in contrast to the unbending position that might have been offered. There will be those who, perhaps unable to view the question of euthanasia through the particular religious lens of the Church of England, will share similar anxieties about the repercussions of legalising assisted suicide.

The highly publicised efforts of motor neurone disease patient Diane Pretty to secure her "right to die" have once again stirred the sometimes dormant but ever present debate over euthanasia. The media coverage has brought into focus now well rehearsed positions-where respect for autonomy and individual choice compete with sanctity of life and "slippery slope" arguments. On Dying Well reiterates these arguments but also offers new insights and analysis. It is worth noting that in the same week that Diane Pretty's case made the headlines, Dame Cicely Saunders, a contributor to the church's report, was awarded the \$1m Hilton Humanitarian Prize for her hospice work in the care of the dying. The philosophical debate surrounding euthanasia has reached an impasse. The "solution" for now, appears to lie in allowing death with at least some degree of self regulation but without appeals to changes in the law.

L Campbell

\section{Bio Engagement: Making a Christian Difference through Bioethics Today}

Edited by N M de S Cameron, S E Daniels, B J White. William B Eerdmans Publishing Company, 2000, £14.99, pp $265+$ xiii. ISBN 0-8028-4793-5

This book is concerned with advocating a prolife stance rather than with detailed discussions of the medical ethics of biotechnology. The essays are written from the particular Christian perspective of conservative evangelicanism and the writers are committed to the verbal inspiration of scripture. It is a book which will be of interest to a certain section of the Christian church. One constraint with this approach is the sense of the discussion taking place "in house", calling Christians of like mind to defend a pro-life stance on health care. Occasionally writers with contrasting points of view are mentioned but there is no sustained discussion of their arguments. The pervasive advocacy of the pro-life view only occasionally yields to a recognition of the complexity of the issues and the general, unacademic, level of the discussions does not provide any detailed argument and support 
for the ethical presupposition of the book, which is simply assumed.

This is a work that takes its cue from the idea of "engagement"; the wide ranging discussions of biology and biotechnology currently taking place are not covered, rather the focus is on abortion, and to a lesser extent, euthanasia. Several essays show how Christians holding pro-life views can best make their position known, how to defend their view in encounters with the media and what to do when moral perplexities are presented in clinical practice or training. Case studies are used to support the overall programme of the book and are not subject to the analysis which might have been expected.

More technical, ethical discussion occurs in the section Law and public policy, where there is an awareness of the complexity of the issues relating to the use of unfertilised eggs which might later be fertilised. And in Casey's essay, How the law will shape our life and death decisions: the case of the human embryo, there is detailed discussion of various important court cases in the United States. But here again the argument seems to presuppose too much to make his case convincing no matter how interesting the hints towards ethical solutions might be. In keeping with the theme "making a difference", Casey concludes his paper with a proposal for legislation. There is an interesting criticism in this section of the liberal outlook, namely that liberalism ends in its response to those who object to liberalism.

Overall then there is a paucity of technical discussion of medical ethics in this book. Even the practical discussions are couched in the manner of advocacy rather than analysis. The particular Christian perspective does not seem likely to make the book useful from the point of view of developing discussion even among Christian ethicists. Christian medical practitioners who share the outlook of the author will be encouraged to advance their views in the present climate of opinion, where decisive battles are won by political lobbying. But even some who are sympathetic to the stance of this book, including this reviewer, will demand more sustained argument and sophisticated presentation of their view.

N Fennemore

\section{Textbook of Research Ethics: Theory and Practice}

$S$ Loue. Kluwer Academic/Plenum Publishers, 2000, US $\$ 55.00$ (hb), pp 255+xix. ISBN 0-306-46448-9

Research ethics is high on the agenda of medical ethics and regulatory topics worldwide at the moment. In this field it is thus important to have good textbooks, to educate health care professionals, researchers, ethicists, students, and policy makers about the nature of research ethics, its history and social contexts. Professor Loue's book is thus published in an increasingly competitive marketplace.

The book has many merits. It consists of five chapters and two appendices. The first chapter summarises several of the iconic scandals in medical ethics, notably the Tuskegee syphilis study and the Nazi doctors' atrocities. The historical scholarship of this chapter is solid, if not original, and it is useful to have it gathered here in a convenient place. There is a serious debate to be had about the pedagogy and philosophy of starting research ethics from a consideration of its worst breaches: does this blind students to the myriad of more minor but more pressing problems that arise in "routine" research? Does it encourage the thought that ethics is about hard cases only? Does it take seriously the fact that research ethics is, historically speaking, an evolving discipline? Nevertheless, this is the traditional place to start, and Loue does it very well.

The second chapter summarises some of the main theoretical positions in bioethics. This is the weakest chapter in the book several times stating a thumbnail sketch of a position (for example, lesbian ethics) with a list of pros and cons before moving on. A survey is always vulnerable to this fault, of course. More seriously, in my view, these views are set out, but few of them are seriously illustrated in the remainder of the book. A more ambitious book would have given a more thorough sketch of what, for instance, Gilligan's ethics of care would say about HIV vaccine trials in the Third World. The promise of non-utilitarian, nonprinciplist approaches in research ethics has often been asserted, but rarely has a serious attempt been made to apply them in a systematic way.

Chapters three and four analyse the ethical issues that arise in study design and implementation. These chapters are very competently done, but focus in the main on consent and confidentiality, with interesting materia (and this is unusual) on conflicts of interes and the rights and duties of the controller of research data relating to publication and use. Chapter five is a valuable account of the regulatory and legal frameworks governing research in the United States. This chapter is of little direct applicability for non-US readers, but is most informative for both students of comparative bioethics and for researchers who wish their studies to have US sites or to be acceptable to US sponsors and regulators. In an increasingly globalised research context, this is a valuable asset. On the other hand, there is relatively little in the book about international research.

The book closes with a pair of appendices, one setting out in some detail the various kinds of research study design and the other setting out the principles of US law. Both of these are very useful and helpful, and should be of great assistance to readers who are unfamiliar with either-a situation common enough, since research ethics interests both the researcher (who may know no law or ethics) and the ethicist (whose grasp of research design may be weak).

The book is not comprehensive: gaps include health services and nursing research, and human rights in medical research. A useful feature is the inclusion of exercises for the reader, although these are very taxing at times, and no model solutions are provided.

In summary this is a valuable textbook, which aptly summarises much of current scholarship in research ethics. It would be suitable for undergraduate or postgraduate courses in medical ethics and in research methods. I find the price of the book rather high, considering the existence of more affordable alternatives. That said, the teacher of research ethics will find this a very useful addition to his or her library.

R E Ashcroft

\section{NOTICES}

\section{6th World Congress of Bioethics}

The 6th World Congress of Bioethics will be held in Brasilia, from 30 October to 3 November 2002. The congress is sponsored by the International Association of Bioethics, the Brazilian Society of Bioethics, the Center for Studies and Research in Bioethics (University of Brazil), the Brazilian Federal Council of Medicine and the Latin American and Caribbean Federation of Bioethics Institutions.

The theme of the congress is bioethics: power and injustice.

For further information please see: www.bioethicscongress.org.br

\section{News from the Centre for the Study of Global Ethics, the University of Birmingham}

The new weekend short course programme includes Global Bioethics (June) and Development Ethics (September).

The new MSc in Global Ethics begins in October 2002, with modules including: Global Ethics; Globalisation and Governance; Conflict Humanitarian Aid; Non-Governmental Organisations in a Changing International Context; Research Methods, and practical placements in non-governmental organisations, as well as the above course topics.

For further information please contact: Helen Harris on +44(0)121 6934687 . 